International Journal of English Literature and Social Sciences
Vol-6, Issue-3; May-Jun, 2021

Peer-Reviewed Journal

\title{
Social Media use and its Effects on writing Ability among Moroccan University EFL Students
}

\author{
Mounim Lakhal
}

Laboratory of Language and Society, Ibn Tofail University, Kenitra, Morocco

Received: 21 Feb 2021; Received in revised form: 29 Apr 2021; Accepted: 12 May 2021; Available online: 29 May 2021

(C)2021 The Author(s). Published by Infogain Publication. This is an open access article under the CC BY license

(https://creativecommons.org/licenses/by/4.0/).

\begin{abstract}
Social Media is part and parcel of our everyday lives. And since millennials have been interacting on social media on a constant basis, writing is one of the skills by means of which they interact. The intent of this paper is to measure students' social media usage and explore the relationship between these technologies and writing ability among Moroccan university EFL students. In particular, this study employs the explanatory sequential mixed-methods design as a means of researching the reciprocity between social media use and its effects on the writing skill. The findings have indicated that Moroccan university students' social media use habits exert significant impacts on the writing skill and that most of them are susceptible to potential risks pertaining to the use of social media. The reported findings gave sufficient proof that social media is a convenient tool to develop better writing skills. Hence, social media literacy should be integrated in the curriculum.
\end{abstract}

Keywords-Social media use, writing ability, academic writing skills, Moroccan university students.

\section{INTRODUCTION}

The strong presence and ubiquity of social media have become an accepted matter of fact. Today's youths are tremendously attached to Internet and social networking. They spend most of their time social networking and text messaging in their daily communication. Their dependency on technology has gone viral and their use of social media has resulted in both positive as well as negative effects. To put it differently, these young generations use social media in a variety of ways ranging from entertainment, socializing and information-seeking.

Given that millennials have been interacting on social media on a daily basis, writing is one of the skills by means of which they interact. Hence, there is a link between social media use and writing ability. Writing is an ability that is very often needed and an essential skill of academic success which merits special attention. is a significant skill which plays a vital role in effective communication. Its proficiency and always been and still remains an elusive goal for most EFL students. Learned from an early age school, the act of writing enables success in academic and professional life. Students' writing performances are judged in job recruitments and promotions at the work place. This crucial skill, therefore, requires greater attention and can be enhanced through social media platforms. Zheng, Yim \& Warschauser (2018) highlight that "writing via social media can provide opportunities for English learners to communicate with native English speakers and practice their written language in authentic and motivating ways" (p. 1). Given the growing role of social media in education, writing via social media platforms becomes a rewarding experience over time. As far as (Zheng et al., 2018) are concerned,

instructional affordances of social media can facilitate students' exchange of ideas and sharing of knowledge, develop their academic identities as authentic writers, strengthen their awareness of audience and authorship, enhance their confidence in and motivation for writing, and ultimately promote their writing skills and language development" (p. 2). 
The present study is an attempt to empirically explore the relationship that exists between social media use and writing ability and to capture how patterns of social media use affects university students' writing abilities. Towards a comprehensive understanding of dynamics of social media use and its effects in boosting writing ability, this study aims to answer two main questions:

Q1: Do university EFL students, who use SM for academic purposes, score higher or lower in writing than their counterparts who do not?

Q2: Is there any relationship between the nature of online activities that learners are engaged in and their writing ability?

Starting from the analysis of the interview and a questionnaire administered to first-year EFL students, the present paper is an attempt to highlight social media use patterns and their effects on students' writing abilities.

\section{LITERATURE REVIEW}

The use of social media in the field of education has undoubtedly brought about many advantages for education stakeholders. Social networking tools are "among the most dominant on the Web today. These services bring people together with common interests, experiences, and activities; allowing people to share their commonalities" (Bonk, 2009, p. 329). Social networking sites help students communicate and share their thoughts and ideas on various topics. This form of e-learning allows asynchronous and synchronous interaction between learners and educators (Salas et al., 2002) owing to a wide range of instructional material such as texts, videos and audios made available via online discussions. These Web tools enable learners to be in charge of their own learning whenever and wherever they want (self-directed learning). E-learning paves the way for 'active learning'; an instruction approach in which learners are asked to engage in the learning process. Unlike 'traditional' modes of learning in which students are mere passive receivers of knowledge, active learning helps students to get engaged in small or large activities centered around speaking, writing, problem-solving, reflecting, etc. Such educational activities, which entail collaborative work, discussions, peer assessment, and the like, can be done with the help of social networking technologies (Liccardi Ounnas, Pau, Massey, Kinnunen, Lewthwaite \& Sarkar, 2007).

To seek and share information, the present generation makes heavy use of social media or social network sites that comprise a wide array of activities that involve socializing and networking online via words and videos, etc. Learning in the context of social media has become highly self-motivated, autonomous, and informal, as well as an integral part of the college experience (McGloughlin \& Lee, 2010; Smith, Salaway, \& Caruso, 2009; Solomon \& Schrum, 2007). Thanks to these social network technologies, users take charge of their own learning by communicating and sharing their concepts on various topics and issues. At present, the most popular and attractive social networking communities include WhatsApp and Facebook.

The virtual sphere has become an educational realm where knowledge and learning becomes the dominant partner. Learning is thus rendered personalized, authentic and spontaneous. The world of multimedia technology has proven useful in promoting learning. First and foremost, it satisfies both auditory and visual senses of learners paving the way for synchronous or asynchronous mode of interaction. Social media abundantly supply users with a wide array of opportunities to participate, react, interact and even consume knowledge by receiving and sharing it.

Individuals participating in social media are communicating, encoding, transmitting, and decoding messages at a basic level. By and large, this communication takes the form of user-generated content (UGC) which is created, shared, and gathered. Communication is predominately efficient. The social process is distant through time and space; individuals can participate anytime and anywhere. Social interactions can equally assist individuals in completing a task or building and maintaining relationships. Or more simply put, social media are virtual places where people can share anything anywhere anytime. In today's modern world of technology, everything that we need to know is available online through the use of social media. You can even express your opinions and thoughts instantaneously on things that have been written or advertised.

A great deal of literature highlights the influence of social networking technologies on students' language proficiency (Kolek \& Saunder, 2008; Karpinski \& Duberstein, 2009; Kirschner \& Karpinski, 2010; Rouis, Limayem, \& Salehi-Sangari , 2011; Paul, Baker \& Cochran, 2012; Michikyan Subrahmanyam, Dennis, 2015). A lot of research has been carried out to determine the nature of the impact on students' language learning and in most cases the positive results outweigh the negative ones. Social network has undoubtedly become the central hub of people's lives and its usage by students is becoming an accepted fact for most.

Social networking technologies, as a means of advanced technology, have exerted a substantial effect on English language learning. The main reason for this is the worldwide proliferation of social networking applications and the ease of access to the world wide net. According to Crystal (2001), one of the world's most eminent linguists, 
social networking technologies drive teenagers to read because they remain glued to screens. He points out that the use of language in texting is something positive rather than negative as it fosters language learning. In his book "Txtng: The Gr8 Dbt8", Crystal (2008) states that "those who text well almost invariably also have an excellent command of their language. Those who write more text seemingly also both write more, and better, Standard English" (p. 306). Therefore, the more they write, the better their writing skill becomes as well as their communicative competence. In the same vein, Crystal (2001) argues that "Internet users are continually searching for vocabulary to describe their experiences, to capture the character of the electronic world, and to overcome the communicative limitations of its technology" (p. 67). Thanks to technology, students can form an online writing community that helps them to reduce the stress of writing encountered within the class borders. According to Choi (2008), the rationale for using technology in the writing process is that "good writing may be made possible by creating a sense of audience/community in writing, attaching importance to feedback and revision, reducing stress of writing and enhancing mutual help" (p. 35). Therefore, with the creation of an online writing community, learning has become more learner-centered and egalitarian, thus turning out to be less intimidating and more accessible.

In the past twenty years, the field of computer mediated interaction has greatly diversified in scope. Warschaur \& Grimes (2007) describe the various forms of interaction facilitated by the latest features of computer technology, often referred to as Web 2.0, including blogs, wikis, and social networks. These new developments provide opportunities for new types of interaction and collaborative activities. For instance, FB allows students to share messages, chat and exchange photos and videos (Cloete, De Villiers \& Roodt, 2009). Therefore, using FB or WhatsApp as a medium for practicing writing through groups will enable students to brainstorm ideas, write freely and edit their classmates' written work. Teachers can post a topic to be discussed and share photos for visual stimulus to activate students' schemata. Through writing reflections in the group, students can enhance peer-work skills and develop their expression ability. The social network can offer a more relaxing learning atmosphere where students are not only able to develop their writing skills but to collaborate with each other. Thus, the problem of finding a platform for writing activities may be solved with the usage of Facebook and WhatsApp.

The effects of social media in the field of education have been discussed and argued by many educational scholars since the inception of these platforms. However, the questions that arise here are: Is there any relationship between social media use and writing ability? Is social media beneficial or detrimental to the writing skill? In other words, does social media use have positive effects on students' assessments and examinations?

Social media has tremendously facilitated learning and broadly impacted the nature of learning in higher education as never before. Different researchers conducted research to see the influence of social media on users' academic performance and found positive relations between the use of SNSs and writing ability. Quader (2014) found that students who use SNSs score higher on reading skills test and had higher grades than their counterparts who do not. Quader (2014) also asserts that social media platforms offer greater opportunities for students to expand their learning by freely discussing various subjects unlike in formal classroom contexts where they might feel uncomfortable to communicate their ideas and thoughts. Another research was conducted by Kabilan et al. (2010) to see if Facebook supports or boosts language learning in English. The result of their findings indicates that Facebook does boost students' motivation, confidence and attitudes towards English language learning. Also, $74.1 \%$ of the students claim that participation in Facebook instills positive attitudes towards English language learning. In short, Kabilan and his colleagues' research indicates that Facebook motivates students to improve their reading skill and hone their writing skills in particular. In the same vein, Bani-Hani, Al-Sobh \& Abu-Melhim, (2014) undertook a study in Jordan to investigate EFL University students' perceptions and attitudes towards utilizing Facebook groups in teaching writing as well as the role Facebook groups play in enhancing writing performance level. They found that "utilizing a Facebook group in language instruction does indeed assist in language acquisition and helps to better develop writing skills, particularly in the pre-writing phase, as well as helps students to better develop their vocabulary and lessen spelling mistakes" (Bani-Hani et al., 2014 , p. 33). Another study was made at the University of Bahrain by Harrath and Alobaidy (2016) to explore the relationship between the use of SNSs and Arabian Gulf students' academic performance. These researchers found a positive impact of social media platforms on students' academic level through optimal use of social networking sites. These students, as this study concludes, display sheer awareness of using social networks for educational purposes. Another study was conducted by Mahamat (2014) to obtain Malaysian university students' perceptions on how their use of SNSs impacts their academic performance. The results of this study showed that a great proportion of students concurred that SNSs 
impacts positively their academic performance. In the same vein, Gremu and his colleague Halse (2012) argued that

\begin{abstract}
students are however, keen to use SNSs for academic purposes and this presents an opportunity to engage them to learn informally by seeking, exploring and testing ideas with other students within their own social network (Gremu et al.,p.2)
\end{abstract}

Junco, Heibergert \& Loken (2011) conducted a longitudinal study to see the link between social media use and students' grades. These scholars split students into two groups. One group used twitter for academic purposes while the other did not. The result of their study indicates that students in the Twitter group have higher GPAs than their counterparts. Other scholars like Obi, Bulus, Adamu \& Sala'at (2012) came to the conclusion that social media usage results in language deterioration in that students get unconsciously accustomed to using abbreviations while chatting with other users and hence reproducing the same errors in formal writings. Similarly, an interesting study made by Mingle, Adams, \& Adjei (2016) on social media usage and academic performance in public and private high schools revealed that a large proportion of students use WhatsApp and Facebook more often and that students from the private schools spend more hours online as compared to their counterparts in the public schools. Findings of this study also came up with the conclusion that these students witnessed a drop in grades due to their misuse of these technological tools. Mingle et al. (2016) concluded that these students need counseling for their addiction.

Among the main findings of an online survey of 2462 Advanced Placement (AP) and National Writing Project (NWP) teachers is that social media applications are useful tools that help students improve their writings. The result concludes that " $96 \%$ agree (including 52\% who strongly agree) that digital technologies "allow students to share their work with a wider and more varied audience". $79 \%$ agree (23\% strongly agree) that these tools "encourage greater collaboration among students". And, $78 \%$ agree (26\% strongly agree) that digital technologies "encourage student creativity and personal expression" (Purcell et al., 2013). This group of AP and NWP teachers advises that students' formal writings see a 'creep' of informal language and style which is due to the use of digital technologies. On the question of using informal language in academic writings, a study was conducted by González (2003) which she entitles: "Teaching and learning through chat: A taxonomy of educational chat for EFL/ESL." She pointed out that online communication, which is characterized by short forms and incomplete sentences, exerts a negative influence on students academic writings at the level of grammar and spelling. Moreover, the nature of writing in chat rooms is different from the one in a classroom. Students, therefore, are required to discern between the informal and the academic forms of writing. In the same line of thought, Madge, Meek, Wellens \& Hooley (2009) undertook a study to examine students' perceptions on the use of Facebook in the learning process. The finding of their study generally revealed that Facebook is an effective learning tool for students and that undergraduate students regarded its usage a convenient outlet to informal rather than formal learning. Similarly, Selwyn (2009) undertook a study titled "the digital native-myth and reality" and found that online communication through social media platforms affects negatively students' writings due to the fact that students get used to informal writing structures. White (2009) undertook a tremendously significant five-week study titled: "The use of Facebook to improve motivation and academic writing" on Japanese university students to see whether or not Facebook contributes to effective learning by creating a discussion group in Facebook. This scholar proceeded by providing, each week for five weeks, a question for discussion on Facebook. Students received prompt feedback on their writings. In their first week of the discussion group, 87 grammar mistakes were noted. These types of mistakes were actually due to students' use of informal English. The teacher gave them feedback in this area and addressed common issues pertaining to their writings for improvement sake. The second week saw a decrease in terms of grammar mistakes by almost two thirds. The teacher kept their progress under watch using four elements, namely grammar mistakes, spelling mistakes, words written and motivation. Once spotted, common grammatical mistakes were posted on the Facebook group wall for discussion. Hence, students learnt from their own and their peers' previous mistakes and heeded the grammar advice for further writings. At the end of the fifth week, they witnessed great improvements in grammar and spelling. White (2009)'s study came up with the conclusion that Facebook contributes to positive learning outcomes on students' written assignments as well as on their motivation for learning. This idea is corroborated by Promnitz-Hayashi (2011) in his study titled: "A Learning Success Story Using Facebook" by asserting that "simple activities in Facebook helped a lower language proficient class to become more comfortable participating in online discussions, giving their opinions and forging closer relationships with their fellow classmates" (Prominits-Hayashi, 2011, p. 309). Likewise, a similar study conducted in Taiwan by Wang, Lin, Yu, Wu (2013) yielded the same result. In this study, 
students demonstrated positive attitudes toward language learning, participated in online discussions in an enjoyable and motivating way and were able to build confidence as well. Similarly, McCarthy (2010) confirmed similar results in his four year study to evaluate the use of Facebook as an online learning environment between 2008 and 2011. Among the key findings of his study is that Facebook is an educational tool that "negates key pitfall such as language barriers and social inhibitions" (McCarthy, 2010, p. 341). A very recent study, conducted by Chepkemoi, Situma \& Murunga (2018), sought to probe the impacts of social media use on students' written assignments. These scholars found that informal language creeps into students' academic writings. Accordingly, this study recommends that students should write formal English in social media platforms.

Broadly, studies on the relationship between social media use and writing ability are not all homogenous and consistent. Some argue in favor of the beneficial academic aspect of social media use while others argue just the opposite. In a nutshell, different uses of social media applications and how users use technology is a determining factor which impacts students' writing performances. Certain uses result in good productivity while other uses lead to language deterioration.
Interestingly enough, and based on the results, it can be said that the studies claiming negative relationship between social media use and writing ability share one thing in common and that is the use of social media for non-academic use. Accordingly, the nature of usage does have an impact on students' performance. In other words, using social media positively for educational purposes is a sure fire way to bring about positive outcomes in students' writing performances. Many researchers place the blame on the habits of technology users rather than on social media websites per se. In order to generate positive results and achieve academic success, it is up to technology users to create a balance between social media and academic activities. Asad, Mamun, \& Clement (2012) conclude that “students' academic learning outcomes could increase when their social learning outcomes were heightened" (p. 501).

\section{RESEARCH METHODOLOGY}

To answer the research questions and find evidence for the identified hypotheses, the researcher adopts an explanatory sequential mixed methods approach consisting of quantitative and qualitative phases. Figure 1 clearly illustrates the phases incrementally followed in this study:

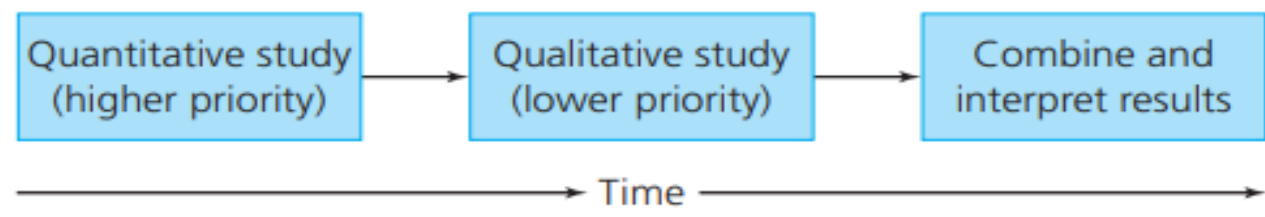

Fig.1: The Explanatory Mixed Methods Research Design of the Study

(Fraenkel et al., 2012, p. 561)

In the explanatory mixed methods design, the researcher begins by collecting and analyzing quantitative data then moves on to deal with qualitative data so as to explain, interpret or back up the quantitative data results. This design helps the researcher to link the strengths of both quantitative and qualitative methods. In dealing with an issue that is as intricate as social media use and its reciprocity with writing ability, the objectives of the present study can only be achieved with a study design that makes use of both quantitative and qualitative data. This method of inquiry is adopted because the findings obtained from both quantitative and qualitative methods can complement each other in a way that helps the researcher to have an in-depth look into the relations between the variables. As well, the quantitative and qualitative findings enable the inquirer to gain a deeper understanding about the participants' subjective experiences and perceptions and eventually come up with clearer and more insightful conclusions (Creswell, 2003).

In this study, the final target population consisted of $n=243$ of Moroccan first-year university students from the department of English at Moulay Ismail University, school of Arts and Humanities. The respondents were selected on the basis of their proximity and convenient accessibility to the researcher.

To collect quantitative data, the researcher uses a cross-sectional close-ended questionnaire and a writing test as the primary data collection instruments. After identifying students who use social media for educational purposes and their counterparts who use it for recreational ends, the researcher invited them for a writing test to gauge their writing performances. The researcher then went about assessing the pieces of writing using a checklist to obtain more consistent grading decisions. The researcher made use of the findings from the qualitative phase to flesh out the quantitative study. In the qualitative 
phase, the inquirer employed semi-structured interviews as a data collection tool to get an in-depth and comprehensive understanding of respondents' attitudes and lived experiences vis-à-vis social media use. Again, to select the participants for the interview, the researcher employed a purposive sampling technique. The collected data from the interviews were analyzed using a thematic analysis and merged with the quantitative results to gain in-depth and comprehensive understanding of phenomenon under study.

\section{DATA ANALYSIS AND DISCUSSION}

Given the nature of the research questions dealt with in this phase, both descriptive and inferential statistics were used in the analysis of data. The researcher made use of Spearman Rho correlation coefficients' inferential statistical test. This non-parametric statistical test was used to measure the degree of association between students' social media usage and the level of impact this has on their writing abilities. In this study, this test was used to test the relationship between the mean score of social media usage scale and students' writing ability. Accordingly, the result below 0.05 is a perfect positive correlation and above signifies a negative correlation.

To get an idea about the social media platforms that university students use the most, the results, graphically visualized in Figure 2, reveal that WhatsApp comes at the top of the list with a percentage of $(50,2 \%)$ followed by Facebook with (37\%). On the reverse, the respondents' use of Google plus and Twitter platforms is considerably low with $(7 \%)$ and $(5,3 \%)$ respectively. WhatsApp is used by a large proportion of participant students followed by Facebook, Google plus, Twitter and other rarely used platforms. It is axiomatic to assert that the preferred websites present an array of features that meet users' expectations and thus render them appealing. The useful services and facilities provided by WhatsApp and Facebook and which respond to online users' needs and tendencies play a great role in influencing users' acceptance and use of this technology. It is not surprising to notice the considerable rise in popularity these applications undergo.

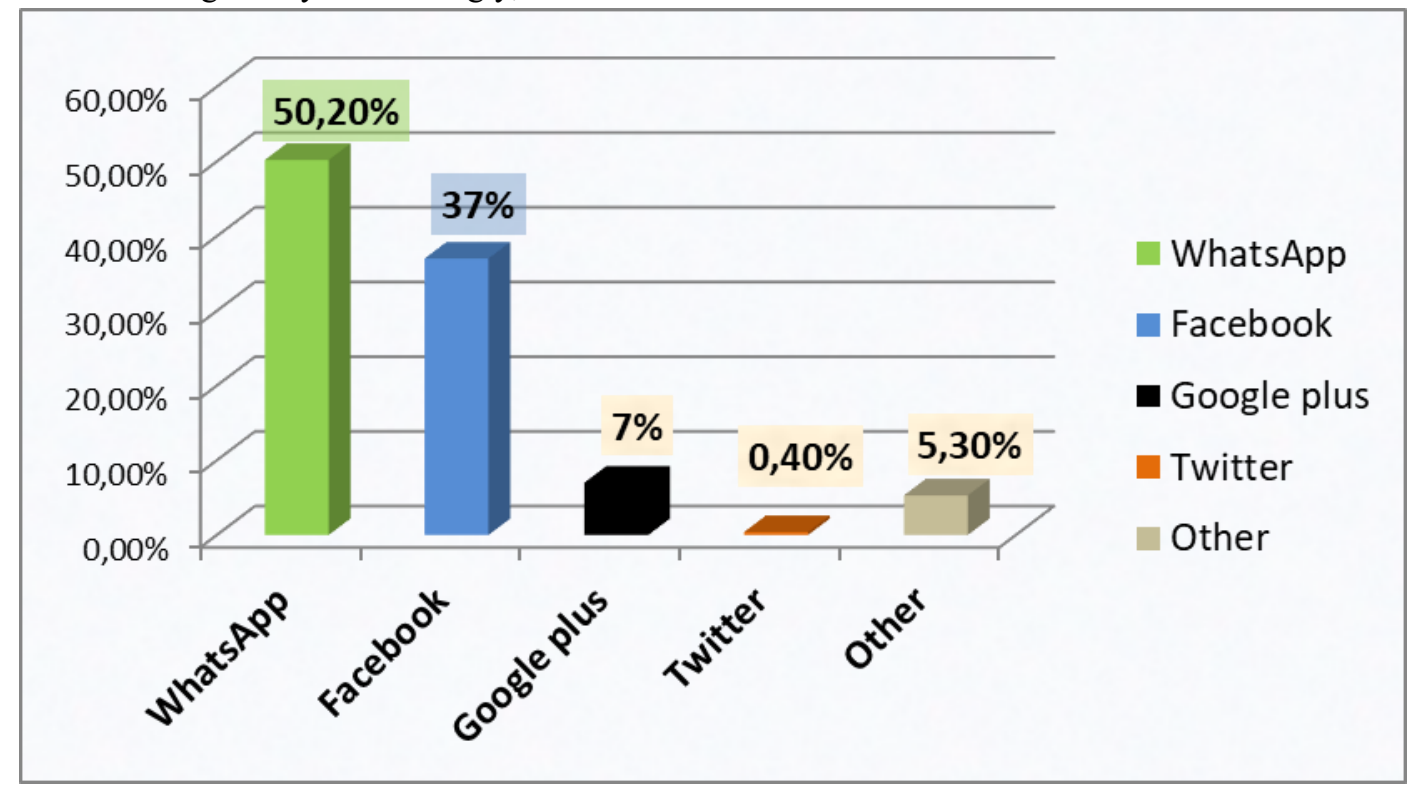

Fig.2: Most Frequently Used Social Media Apps

In order to explore students' perceptions apropos the impact social media exerts on their academic performance, students were asked if they think social media use, in general, benefit them academically in any way. The overwhelming majority said that social media does indeed benefit them academically. Figure 3 indicates $87.7 \%$ of the respondents answered favorably while only $12.3 \%$ responded negatively. 


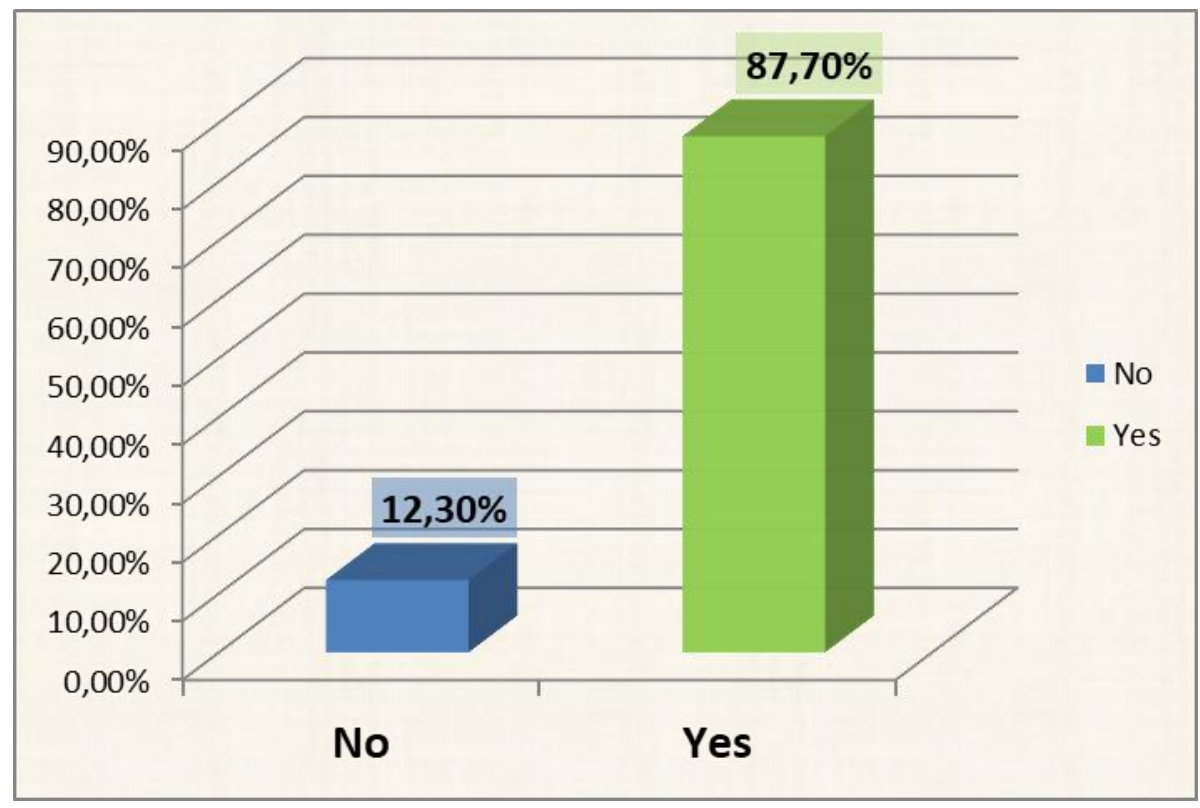

Fig.3: The distribution of the students in terms of whether SM benefit them academically.

One of the most critical research questions the present study is trying to answer is whether social media users for academic purposes score higher or lower in writing than nonusers. Figure 4 shows that $66.70 \%$ got a B grade for their writings, $27.40 \%$ had $\mathrm{C}$, while $3.80 \%$ and
$2.20 \%$ obtained $\mathrm{F}$ and A respectively. These findings clarify that a large proportion of students who use social media for academic purposes achieve satisfactory results in writing.

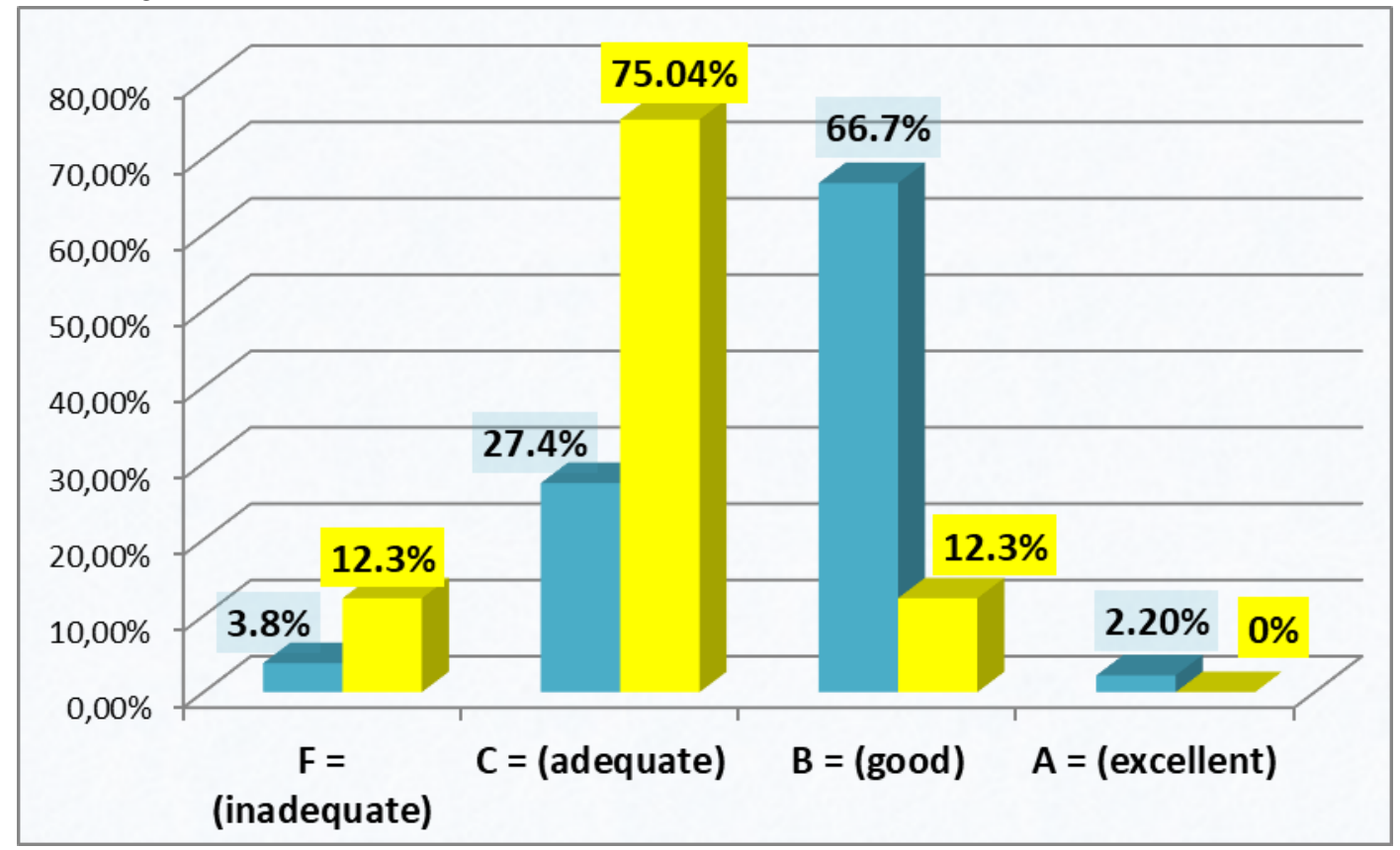

Fig.4: The Distribution of the students in terms of their writing test results-SM users for academic purposes versus SM users for recreational ends.

The analysis of data, as indicated in Figure 4, reveals that students who use social media for academic purposes had higher writing scores than their counterparts who do not. Precisely, $66.7 \%$ of social media users got a 'B' grade, compared to only $12.3 \%$ of nonusers. Also,
$12.3 \%$ of social media nonusers got ' $\mathrm{F}$ ' outnumbering thus their counterparts with $3.8 \%$. One possible explanation for such score-related differences lies in the nature of engagement in social media applications and how users use technology. That is to say, the way in which users use 
technology is a determining factor which impacts students' productivity. Certain uses do undoubtedly result in poor writing performance while other uses lead to good productivity. It is up to the individual user and how s/he perceives technology use.

The students were asked to specify the types of mistakes they make when they write. This question was meant to investigate the nature of problems that characterizes students' writings. The findings, as Figure 5 highlights, indicate the following: $30.5 \%$ of the students said that they have problems with spelling; $25.1 \%$ with verb tenses; $10.7 \%$ with punctuation; $5.3 \%$ with plural forms; $2.5 \%$ with capitalization and $25.9 \%$ said that they have other problems related to the language structure.

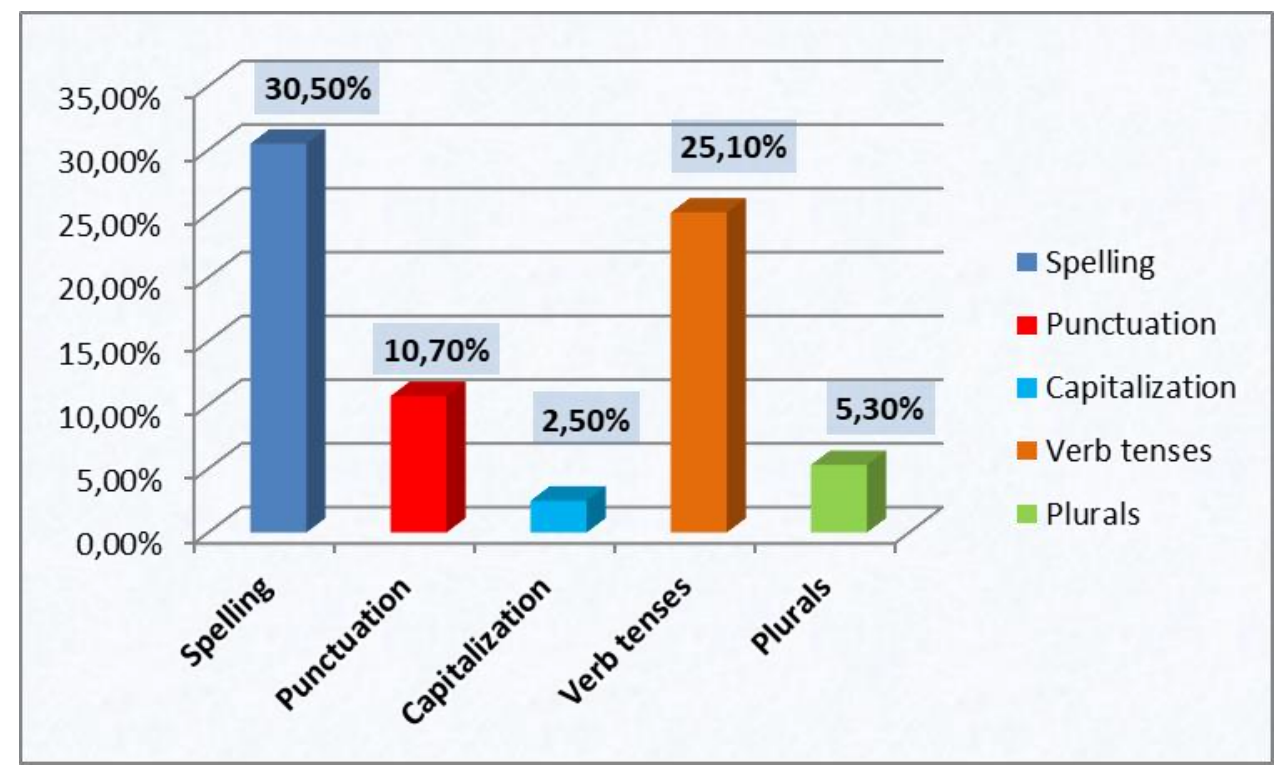

Fig.5: The Distribution of the students in terms of the types of mistakes they make in academic writing.

\section{Correlations between Miscellaneous Online Activities and the Scores of the Writing Test}

One of the most important aims of this study is to comparatively examine the nature of various activities students embark on, while they get online and writing ability. To achieve this goal, a Spearman's Rank

Table 1: Spearman's Correlations between SNS Use for the Sake of Interaction and Seeking Help and the Writing Test Scores
Correlation was conducted to measure the strength and direction of the relationship between SNS use for the sake of interaction and seeking help and Students' scores of the writing test. A two-tailed test of significance indicated that there was a weak, significant, positive relationship between SNS use for the sake of interaction and seeking help and writing ability $\mathrm{rs}(243)=.010, \mathrm{p}<.05$.

\begin{tabular}{|c|c|c|c|c|}
\hline & & & $\begin{array}{l}\text { Writing Test } \\
\text { Scores }\end{array}$ & $\begin{array}{c}\text { The Use of SNS to } \\
\text { Connect, Interact and } \\
\text { Seek Help }\end{array}$ \\
\hline \multirow[t]{2}{*}{ Spearman's rho } & Writing Test Scores & $\begin{array}{l}\text { Correlation } \\
\text { Coefficient } \\
\text { Sig. (2-tailed) } \\
\text { N }\end{array}$ & $\begin{array}{c}1.000 \\
\cdot \\
243\end{array}$ & $\begin{array}{l}.143^{*} \\
.010 \\
243\end{array}$ \\
\hline & $\begin{array}{l}\text { The Use of SNS to Connect, } \\
\text { Interact and Seek Help }\end{array}$ & $\begin{array}{l}\text { Correlation } \\
\text { Coefficient } \\
\text { Sig. (2-tailed) } \\
\text { N }\end{array}$ & $\begin{array}{l}.143^{*} \\
.010 \\
243\end{array}$ & $\begin{array}{c}1.000 \\
\cdot \\
243\end{array}$ \\
\hline
\end{tabular}

*. Correlation is significant at the 0.05 level (2-tailed). 
As well, a Spearman's Rank Correlation was run to measure the strength and direction of the relationship between the use of SNS for collaborative learning and the writing test scores. A two-tailed test of significance indicated that there was a weak, significant, positive relationship between and the use of SNS for collaborative learning and students' writing ability $\mathrm{rs}(243)=.009, \mathrm{p}<$ .05 .

Table 2: Spearman's Correlations between the Use of SNS for the Sake of Collaborative Learning and the Writing Test Scores

\begin{tabular}{|c|c|c|c|c|}
\hline & & & $\begin{array}{c}\text { Writing Test } \\
\text { Scores }\end{array}$ & $\begin{array}{l}\text { The Use of SNS for the } \\
\text { Sake of Collaborative } \\
\text { Learning }\end{array}$ \\
\hline \multirow{6}{*}{ Spearman's rho } & \multirow[t]{3}{*}{ Writing Test Scores } & $\begin{array}{l}\text { Correlation } \\
\text { Coefficient }\end{array}$ & 1.000 & .133 \\
\hline & & Sig. (2-tailed) & . & .009 \\
\hline & & $\mathrm{N}$ & 243 & 243 \\
\hline & \multirow{3}{*}{$\begin{array}{l}\text { The Use of SNS for the } \\
\text { Sake of Collaborative } \\
\text { Learning }\end{array}$} & $\begin{array}{l}\text { Correlation } \\
\text { Coefficient }\end{array}$ & .133 & 1.000 \\
\hline & & Sig. (2-tailed) & .009 & \\
\hline & & $\mathrm{N}$ & 243 & 243 \\
\hline
\end{tabular}

*. Correlation is significant at the 0.05 level (2-tailed).

Again, to answer the research question related to the relationship between social media use and writing ability, a Spearman's Rank Correlation was run to measure the strength and direction of the relationship between social media use and Students' scores of the writing test. A two-tailed test of significance indicated that there was a moderate, significant, positive relationship between scores of writing and social media use for academic purposes $\mathrm{rs}(243)=.475, \mathrm{p}<.05$. Therefore, the null hypothesis stating that there is no correlation between social media use for academic-related purposes and writing ability has been rejected and the alternative hypothesis accepted. The findings suggest that students who use social media for academic-related purposes tend to get satisfactory achievements in writing assignments.

Table 3: Spearman's Correlations between Social Media Use for Academic Purposes and the Writing Test Scores

\begin{tabular}{|c|c|c|c|c|}
\hline & & & $\begin{array}{c}\text { Writing } \\
\text { Test Scores }\end{array}$ & $\begin{array}{l}\text { Social Media } \\
\text { Use for } \\
\text { Academic } \\
\text { Purposes }\end{array}$ \\
\hline \multirow{6}{*}{ Spearman's rho } & \multirow[t]{3}{*}{ Writing Test Scores } & Correlation Coefficient & 1.000 & $.475^{* *}$ \\
\hline & & Sig. (2-tailed) & . & .000 \\
\hline & & $\mathrm{N}$ & 243 & 243 \\
\hline & \multirow{3}{*}{$\begin{array}{l}\text { Use_of_social_media_ } \\
\text { for_academic_purposes }\end{array}$} & Correlation Coefficient & $.475^{* *}$ & 1.000 \\
\hline & & Sig. (2-tailed) & .000 & . \\
\hline & & $\mathrm{N}$ & 243 & 243 \\
\hline
\end{tabular}

**. Correlation is significant at the 0.01 level (2-tailed).

V. IMPLICATIONS AND RECOMMENDATIONS

The findings of the study have proven that social media - WhatsApp as a main preoccupation, have largely dominated the Moroccan university students' online practices, showing both positive and negative aspects. They have also given sufficient proof that social media is a convenient tool to develop better writing skills. 
Significantly, social media have yielded positive outcomes on writing ability when students use it for academic purposes. University students show mindful awareness and healthy attitudes towards using social media in enhancing written communication skills. It has also been found that social media plays a leading role in developing their vocabulary repertoire and grammatical structures through digital media. In light of these findings, this study has important implications for education stakeholders, namely policymakers, teachers and students.

To begin with, policymakers in the realm of education are encouraged to integrate social media literacy in the curricula from an early age so that students acquire and develop sufficient skills to assist them throughout their online journey. Courses in IT skills and media literacy should aim at training the new generation, digital natives, on the nature of social media and the educational opportunities with which it teems. The rationale behind this training is to offer online users a soft empowerment that would raise their learning opportunities and shun the potential risks when they arise. Further, providing teachers with pre-service and in-service training is a sure-fire way towards the attainment of quality education. The latter depends on an enduring professional education and training that would equip teachers with quality learning and teaching techniques, skills and competencies that would help students keep abreast of the pace of the current technologically-driven era. The quality of higher education is bound to shine if these high-priority exigencies are addressed at various educational stages. Schools need to be equipped with teaching materials and technical resources so that the teaching learning process would be conducted in a smooth and effective manner. A successful integration of Information and Communication Technology (ICT) paves the way for the delivery of quality teaching and learning.

Teachers are encouraged to incorporate web-based technologies in and out of the classroom and thus engage students in online educational activities that enhance students' writing skills. EFL teachers are advised to depart from traditional pedagogical methods in favor of a digital method that would increase students' writing abilities. For instance, they can adopt blogging in writing instructions. Blogs can serve as social productive platforms which create a stress-free atmosphere conducive to learning writing skills outside class. What is worthwhile about using blogs is that they provide access to students to socialize, express their ideas freely and share their writing productions with a large online community. In a similar vein, good writers are good readers since they read, comment, interact and freely discuss a wide range of ideas bloggers share among each other. Blogging-based writing practice can dramatically hone students' writing skills in terms of style, diction, structure, language mechanics as well as other writing sub-skills. Educators are recommended to adopt Blogging as a new approach to teach writing and as a part of the EFL pedagogy.

Last but not least, students are recommended to develop a daily writing practice and good habits for forging productive relationships with online community members willing to improve English language and writing skills through social media and available ICT technologies. Students should learn how to make a good use of social media, such as doing group discussions in preparation for exams, having discussions on class assignments, and most important of all decreasing the usage of informal style while texting in chat rooms. Students should develop selfdirected online learning readiness to avail themselves of the educationally promising opportunities and resources that exist abundantly on social media websites. A selfdirected approach to learning is an essential requirement for students to be equipped with the necessary tools to enable them to successfully cope with the growing demands of today's increasingly networked higher education. This approach to learning is a prelude to independent and autonomous life-long learning in which students willingly assume responsibility for their own learning. University students should also be encouraged to smoothly step out from the previous teacher-directed approach experienced in high school - an approach that is characterized by sheer dependence on the teacher- to a self-directed approach prevalent in higher education; university students should be able to set their own learning goals, discern the difference between authentic and fake information, select trustworthy materials, and self-evaluate their learning outcomes. Overall, changing students' negative approach to social media, engaging them in online academic-related activities, inciting them to pursue self-directed learning can all be geared to minimize the potential risks and maximize the benefits of their daily social media usage. Social media is an amazing tool that serves educational role and proved to be a motivating pedagogical tool for English language learning.

\section{CONCLUSION}

Writing well is undoubtedly an ability that is very often needed and an essential skill of academic success which merits special attention. It is therefore imperative to appreciate the impact that writing can have on any career so that coordinated efforts on the part of education stakeholders should be geared towards the development of this critical skill. Students' writing abilities can be affected either positively or negatively depending on how they share and obtain input through written form. In fact, as 
young people interact online with their peers, their locution seems to include informal words, phrases and constructions which creep later into formal writing. It is compelling to reiterate that the online world offers open ended learning opportunities awash with pitfalls for millennials who are required to develop immunity against any prospective threat and keep their language intact. Hence, students' adoption of modern technologies underlines the dire need for shielding formal English against the odd forms of language, which have become commonplace on social media, especially when it comes to instant messaging. Education stakeholders are advised to introduce a sustained education for students on social media use from their early years of learning. They are advised to leverage the power of social media outlets to help strengthen students' writing abilities and talents.

\section{REFERENCES}

[1] Asad, S., Mamun, M. A., \& Clement, C. K. (2012). The Effect of Social Networking Sites to the Lifestyles of Teachers and Students in Higher Educational Institutions.

[2] Bani-Hani, N.A., Al-Sobh, M.A., \& Abu-Melhim, A.H. (2014). Utilizing Facebook Groups in Teaching Writing: Jordanian EFL Students' Perceptions and Attitudes.

[3] Bonk, C. J. (2009). The World is Open, How Web Technology is Revolutionizing Education. San Francisco, C.A.: Jossey-Bass.

[4] Chepkemoi, K. C., Situma, J., \& Murunga, F. (2018). Influence of Facebook Social- Media Usage on Students' Spellings in English Written Assignments in Public Day Secondary Schools in Eldoret North Sub- County. International Journal of Academic Research in Business and Social Sciences, 8(8), 159- 171.

[5] Choi, W-C. (2008). The Role of Online Collaboration in Promoting ESL Writing. English Language Teaching, 1(1), 34-49. Retrieved 14 July 2017, from http://dx.doi.org/10.5539/elt.v1n1p34

[6] Cloete, S., de Villiers, C. \& Roodt, S. (2009). Facebook as an Academic Tool for ICT Lecturers. SACLA '09 Proceedings of the 2009 Annual Conference of the Southern African Computer Lecturers' Association, 16-22 ACM, New York, US.

[7] Creswell, J. (2003). Research Design: Qualitative, Quantitative and Mixed Methods Approaches (2nd ed.). Thousand Oaks, CA: SAGE Publications.

[8] Crystal, D. (2001). Language and the Internet. Cambridge, UK: Cambridge University Press

[9] Crystal, D. (2008). Txtng: The Gr8 Db8. Oxford: Oxford University Press, England, p. 239.

[10] ers0906w.pdf

[11] Fraenkel, J. R., Wallen, N.E. \& Hyun, H.H. (2012). How to Design and Evaluate Research in Education(8th ed). The McGraw-Hill Companies, Inc., New York

[12] González, D. (2003). Teaching and Learning through Chat: A Taxonomy of Educational Chat for EFL/ESL. Teaching English with Technology, 3(4), 57-69.
[13] Gremu, C., \& Halse, M. (2012). The Educational Value of Integrating a Social Networking Platform and a Learning Management System

[14] Harrath, Y., \& Alobaidy, H. (2016). Impact of Social Networking Sites on Student Academic Performance: The Case of University of Bahrain. J. Cases on Inf. Techn., 18, 35-50.

[15] Junco, R., Heiberger, G., \& Loken, E. (2011). The Effect of Twitter on College Student Engagement and Grades. Journal of Computer Assisted Learning, 27(2), 119-132.

[16] Kabilan, M.K., Ahmad, N. \& Abidin, M.J.Z. (2010). Facebook: An Online Environment for Learning of English in Institutions of Higher Education? Internet and Higher Education, 13(4), 179-187. Elsevier Ltd. Retrieved 18 May 2017, from https://www.learntechlib.org/p/108382/.

[17] Karpinski, A, C. \& Duberstein, A. (2009). A Description of Facebook Use and Academic Performance among Undergraduate and Graduate Students. San Diego, California: American National Research Association. pp 119.

[18] Kirschner, P.A. and Karpinski, A.C. (2010) Facebook and Academic Performance. Computers in Human Behavior, 26, pp. 1237-1245. Retrieved 1 January 2016, from https://doi.org/10.1016/j.chb.2010.03.024

[19] Kolek E.A. \& Saunders D. (2008). Online Disclosure; An Empirical Examination of Undergraduate Facebook Profiles", NASPA Journal, 45(1), pp. 1-25.

[20] Liccardi, I., Ounnas, A., Pau, R., Massey, E., Kinnunen, P., Lewthwaite, S., Sarkar, C. (2007). The Role of Social Networks in Students' Learning Experiences. Proceeding of ACM SIGCSE Bulletin, 39, 224-237.

[21] Madge, C., Meek, J., Wellens, J., \& Hooley, T. (2009). Facebook, Social Integration and Informal Learning at University: "It Is More for Socializing and Talking to Friends about Work than for Actually Doing Work". Learning, Media and Technology, 34, 141-155. Retrieved 17 September 2016, from https://doi.org/10.1080/17439880902923606.

[22] Mahamat. H.A. (2014) The Influence Of Social Networking Sites On Students' Academic Performance In Malaysia, International Journal of Electronic Commerce Studies, 5(2),247-254, doi: 10.7903/ijecs.1114

[23] McCarthy, J. (2010). Blended Learning Environments: Using social Networking Sites to Enhance the First Year Experience. Australasian Journal of Educational Technology, 26(6), 729-740

[24] McLoughlin, C \& Lee, M. (2010). Personalized and SelfRegulated Learning in the Web 2.0 era: International exemplars of innovative pedagogy using social software. Australasian Journal of Educational Technology. 26. 2843. 10.14742/ajet.1100.

[25] Michikyan M., Subrahmanyam K., and Dennis J. (2015). Facebook Use and Academic Performance among College Students: A Mixed-methods Study with a Multi-ethnic Sample, Computer in Human Behaviour, 45(1), pp. 265272.

[26] Mingle, J. Adams M. \& Adjei E.A. (2016) A Comparative Analysis of Social Media Usage and Academic 
Performance in Public and Private Senior High Schools. Journal of Education and Practice 7 (7):13-22.

[27] Obi, N.C., Bulus, L.D., Adamu, G.M., \& Sala'at, A.B. (2012). The Need for Safety Consciousness among Youths on Social Networking Sites. Journal of Applied Science and management (JASM), 14 (1), 39-46.

[28] Paul, J. A., Baker, H. M., \& Cochran, J. D. (2012). Effect of Online Social Networking on Student Academic Performance. Computers in Human Behavior,28(6), 21172127.

[29] Promnitz-Hayashi, L. (2011). A Learning Success Story Using Facebook. Studies in Self-Access Learning Journal, 2(4), 309-316.

[30] Purcell, K., Buchanan, J. \& Friedrich, L. (2013). The Impact of Digital Tools on Student Writing and How Writing is Taught in Schools. National Writing Project. Pew Research Center. Retrieved 26 Febraury 2016, from http://pewinternet.org/Reports/2013/Teachers-technologyand-writing.

[31] Quader, S. B. (2014). Online SNS Usage Patterns of Undergraduate Students in Private Universities of Dhaka, Bangladesh | Shams Quader - Academia.edu. Retrieved from http://www.academia.edu/3521370/Online_SNS_usage_pat terns_of_undergraduate_students_ in_private_universities_of_Dhaka_Bangladesh.

[32] Rouis S., Limayem M., \& Salehi-Sangari E. (2011). Impact of Facebook Usage on Students' Academic Achievement: Role of Self-Regulation and Trust, Journal of Research in Educational Psychology, 9(3), pp.961-994.

[33] Salas, E., Kosarzycki, M. P., Burke, C. S., Fiore, S. M., \& Stone, D. L. (2002). Emerging Themes in Distance Learning Research and Practice: Some Food for Thought. International Journal of Management Reviews, 4: 135-153.

[34] Selwyn, N. (2009). The Digital Native - Myth and Reality. Aslib Proceedings, 61, 364-379.

[35] Smith, S. D., Salaway, G., \& Caruso, J. B. (2009). The ECAR Study of Undergraduate Students and Information Technology, Educause Center for Applied Research, 6. $\begin{array}{llll}\text { Retrieved } 5 \text { July 2017, from } & \text { 20 }\end{array}$ http://net.educause.edu/ir/library/pdf/ers0906/rs/

[36] Solomon, G., \& Schrum, L. (2007). Web 2.0: New Tools, New Schools. Eugene, Or: International Society for Technology in Education.

[37] WANG, J, Lin, C, Yu, W, WU, E. (2013). Meaningful Engagement In Facebook Learning Environments: Merging Social And Academic Lives. Turkish Online Journal of Distance Education, 14 (1), 302-322. Retrieved 14 November 2016, from https://dergipark.org.tr/en/pub/tojde/issue/16895/176034

[38] Warschauer, M., \& Grimes, D. (2007). Audience, authorship, and Artifact: The Emergent Semiotics of Web 2.0.Annual Review of Applied Linguistics 27, 1-23.

[39] White, J. (2009). The Use of Facebook to Improve Motivation and Academic Writing. Proceedings of the Third International Wireless Ready Symposium, 28-32.
[40] Zheng, B., Yim, S. \& Warschauser, M. (2018). Social Media in the Writing Classroom and Beyond. The TESOL Encyclopedia of English Language Teaching, 1-5. 